\title{
DISAGREEMENT OVER THE HESSIAN MILITARY STATE OF THE EIGHTEENTH CENTURY
}

Peter Taylor's response to Charles Ingrao's review, in Central European History, vol. 27, no. 4, of Peter Taylor's Indentured to Liberty. Peasant Life and the Hessian Military State, 1688-1815.

The purpose of a book review (as I was taught) is to summarize a work for a scholarly audience and to point to ways in which its argument may be legitimately contested and thereby to contribute to an ongoing historiographical debate. Charles Ingrao's review of my book Indentured to Liberty: Peasant Life and the Hessian Military State, 1688-1815, only reaches this plane one. More often, it remains mired at a level which confuses fundamental interpretive issues and misreads text in important ways. Thus, its greatest problem is that its representation of my book bears only a shadowy resemblance to the one I wrote.

Ingrao initially (and mistakenly) summarizes my argument as "... HesseCassel's greedy rulers indentured their own people to the maintenance of a 'subsidy army' that helped sustain Great Britain's fabled liberties against the danger of maintaining a standing army of its own. As a result, Hessian society was thoroughly rationalized by its brutally authoritarian government" (p. 509). In fact I argued that the process of providing subsidy troops produced unintended irrationalities including divided personalities, families, communities, and elites (pp. 258-59), although I also suggest that money from the subsidy business allowed the Hessian Landgraves “. . . to build more elaborate states, and more 'rationalized' bureaucracies ... than they otherwise might have built..." (p. 257). The reviewer has clearly conflated "state" and "society" and has reduced my complex and nuanced argument about supposedly "rational" bureaucracies and the unintended (and irrational) consequences of their actions for the society that they administered into a crude and reductionist account. "Greed" was never an issue that I raised.

The reviewer also quotes me as arguing "'the subsidy system ... formed the historical basis for a new capitalist mode of production within the interstices of England's tributary and kin-ordered social formation"' ( $p$. 509). The full passage from my book reads, "The entire ensemble of practices of the English fiscal-military state of which the subsidy system was a crucial part formed the historical basis for a new capitalist mode of production within the interstices of England's tributary and kin-ordered social formation..., etc." (Taylor p. 257). By using the ellipses Ingrao has changed a subordinate clause into the subject of the sentence and a 
highly qualified and multicausal statement into a monocausal and certainly silly interpretation.

The reviewer misrepresents an entire chapter of complicated quantitative evidence by too narrowly focusing on an "... increase in weddings in a small village of Oberweimar after 1762 as evidence of a conscious effort to circumvent the new Canton Reglement" (p. 510). He continues “... yet he [Taylor] never considers the obvious possibility that the increase was a consequence of the simultaneous end of the Seven Years' War, which had caused many couples to postpone wedding plans-and had also increased parental mortality-and thus the marriage prospects of surviving heirs" (p. 510). Aside from the fact that the alternative interpretation suggested by the reviewer was considered and rejected (p. 180), the core of the argument about intentional draft evasion relies not on increases in the numbers of marriages but on changes in the pattern the first marriages of males took after the institution of the draft law of 1762 (pp. 180-90). If Ingrao had wished to engage in serious debate here, he could have taken issue with my divergence from standard procedures of historical demography to describe the patterns of fertility and nuptuality. (I stand by my procedures for my purposes because they highlight issues I am trying to raise, whereas standard demographic operating procedure would blur and obscure them. However, I recognize that they reduce the comparability of the data in the context of pure demographic history and may result in confusing statements when juxtaposed to such material.) In any case, the quantitative evidence from the nine villages of the parish of Oberweimar after 1762 shows significant changes in marriage and devolutionary behavior both above and below the property holding levels established by the Hessian state for the purposes of draft exemption. These results in combination with the testimony of the administering authorities of the region (p. 180) to say nothing of appearance of such coded strategies in folktale evidence (pp. 240-42), strongly suggest that some peasants adjusted their behavior to the exigencies of the selective service system. Though none of these bits of evidence are by themselves conclusive, they move the interpretation from merely a plausible explanatory hypothesis to a greater degree of probability. It has been my experience that rural life is simply too complicated for us to reach a degree of certainty where I would be comfortable using the word "proof."

Ingrao writes that, when I analyze the Hessian draft law of 1762, I "never examine the recruiting instructions of other countries like Prussia" (p. 510), and this he uses as an example of a general failure to consider evidence which normalizes Hesse-Cassel in relation to other German states. Not only do I argue that Hessian recruitment instructions were modeled on the Prussian ones (p. 75, and note 1) but I also point out that Prussians had substantial influence in much reform legislation in Hesse-Cassel (pp. $20,41,76$ ). As I argued in my preface, I am not interested in recreating Hesse-Cassel as some kind of "German 'other" but seek to see how some Germans were bound together with processes that created liberties 
we now all enjoy (pp. $x, x i$ ). Hessian rulers were unique only in the relatively high level of "success" that they achieved in their various military and political enterprises.

Statisticians generally agree that it is not the size of samples that matters but their representativeness. Far from conceding that the parish of Oberweimar "was not particularly representative of the rest of HesseCassel" (p. 511) as Ingrao believes, I make an argument to the effect that "work on the parish may make more valid claim to representativeness than might otherwise have been possible" (p. 114). Unlike most parishes, it contained nine villages ranging from classical nucleated villages of mixed grain and livestock farming, through villages dominated by artisan workers, others dominated by agricultural labor for a noble estate, and finally hamlets devoted mostly to livestock tending. It is this variety of villages that makes it a parish more representative of Hessian rural society than most parishes which contained only one village.

Finally, in criticizing something I actually wrote, Ingrao argues that I misrepresent "the Hufen Edikt as a device for forcing younger sons into the military ..." (p. 511). Of course the authors of the inheritance law do not explicitly state such intentions in the text of the law itself. As I wrote, they place this act in the context of acts designed to forestall the division of closed peasant tenures which were repeated every century from the sixteenth on (pp. 73-74). If division of estates had become a major strategy for protecting sons and that some officials were aware of it as I argue, then a more intensive attempt to limit such division should be read in that context. Moreover, as Ingrao argues in his own book, forcing siblings of heirs into alternative employments including the military was a "widespread expectation" for the edict (pp. 120, 134). If I am guilty of misrepresentation here, so too is Ingrao, whom I cited. In his book he cites the same commission of the Hessian Landtag charged with investigating the effects of the legislation in 1778-79 in which several of the reporting officials connected the inheritance law with enhancing the pool of recruits that I do (p. 134). This material includes the explicit statement from the Landrat von Baumbach zu Sontra that I quote in reference to “... the apparently useful policy that all brothers of heirs to an estate who receive their inheritance in cash are held to be dispensable and thus qualified for enrollment in the military ..." (pp. 90-96; StaM, B/5 3242, von Baumbach zu Sontra).

By now one would have hoped that microstudies such as those of Carlo Ginzburg, Natalie Davis, David Sabean, and the one at the core of my book had demonstrated to historians their value in opening new doors and new interpretations to old materials. Though such studies only have a high degree of probability for the specific area or person under study, they do have the advantage of a kind of detail and understanding impossible for interpretations based primarily on legal documents and the observations of interested, sometimes blind, and sometimes perceptive government officials. Moreover, they are based no less on "mountains of 
hard documentary evidence" (p. 511) than broader-gage studies from the past. Indeed, it appears that it is precisely these tensions between different mountains of evidence which I have pointed out that have apparently elicited Ingrao's angry response about “. . . assault(s) on the documentary evidence..." (p. 511).

Ingrao's review of my book is perhaps most unfortunate because he has never really recognized that I was doing something very different than trying to offer a "more balanced interpretation of the Hessian regime" (p. 509). To some extent, the achievements of Ingrao's own book has rendered this latter task "frivolous" (p. 509), at least from the perspective made possible by sources created by its own officials. But this is not the only legitimate research program for these particular circumstances. This is why I defined my task as investigating “... some consequences of a military and financial relationship between England and the German state of Hesse-Cassel..." which had a basic focus on "... the way members of peasant families experienced the new and more complicated forms of domination which grew out of the international trade in military units" (p. ix). To the extent that I treated the Hessian state, I focused exclusively on the ways it mediated the effects of the English demand for troops to Hessian peasants (p. ix). Thus my work, in tracing the effects of a causal nexus, seeks not to balance the books in the narrower context of the Hessian regime but among the broader ironies of the eighteenth century struggles surrounding "rationality" and "liberty." Though I am happy to elicit discussion, in this case I have been compelled to respond because my interpretations and use of evidence have been misrepresented.

Peter K. TAYLOR

ROSARY COLLEGE

\section{Charles Ingrao's Reply}

I have no doubt that Professor Taylor genuinely feels that some of his arguments have been misconstrued and, therefore, misrepresented. That was certainly not my intent. I am quite confident, however, that other scholars who are equally familiar with the subject would have many of the same reactions to what he has to say-and how and why he says it. His response touches on a few issues to which I would like to reply. First, notwithstanding his protestations, the book and the rhetoric it employs fail to place Hesse-Cassel in the proper context of other German states. Second, although I mistakenly alluded to Oberweimar as a village (instead of a parish, with nine villages), I based my criticism on the tiny numbers of people cited in his tables, rather than on the number of villages. Third, I believe his response also continues to misrepresent the intent behind the Hufen Edikt, not only by ignoring the existence of massive archival evidence that shows the deep concern over declining subsistence levels 
hard documentary evidence" (p. 511) than broader-gage studies from the past. Indeed, it appears that it is precisely these tensions between different mountains of evidence which I have pointed out that have apparently elicited Ingrao's angry response about “. . . assault(s) on the documentary evidence..." (p. 511).

Ingrao's review of my book is perhaps most unfortunate because he has never really recognized that I was doing something very different than trying to offer a "more balanced interpretation of the Hessian regime" (p. 509). To some extent, the achievements of Ingrao's own book has rendered this latter task "frivolous" (p. 509), at least from the perspective made possible by sources created by its own officials. But this is not the only legitimate research program for these particular circumstances. This is why I defined my task as investigating “... some consequences of a military and financial relationship between England and the German state of Hesse-Cassel..." which had a basic focus on "... the way members of peasant families experienced the new and more complicated forms of domination which grew out of the international trade in military units" (p. ix). To the extent that I treated the Hessian state, I focused exclusively on the ways it mediated the effects of the English demand for troops to Hessian peasants (p. ix). Thus my work, in tracing the effects of a causal nexus, seeks not to balance the books in the narrower context of the Hessian regime but among the broader ironies of the eighteenth century struggles surrounding "rationality" and "liberty." Though I am happy to elicit discussion, in this case I have been compelled to respond because my interpretations and use of evidence have been misrepresented.

Peter K. TAYLOR

ROSARY COLLEGE

\section{Charles Ingrao's Reply}

I have no doubt that Professor Taylor genuinely feels that some of his arguments have been misconstrued and, therefore, misrepresented. That was certainly not my intent. I am quite confident, however, that other scholars who are equally familiar with the subject would have many of the same reactions to what he has to say-and how and why he says it. His response touches on a few issues to which I would like to reply. First, notwithstanding his protestations, the book and the rhetoric it employs fail to place Hesse-Cassel in the proper context of other German states. Second, although I mistakenly alluded to Oberweimar as a village (instead of a parish, with nine villages), I based my criticism on the tiny numbers of people cited in his tables, rather than on the number of villages. Third, I believe his response also continues to misrepresent the intent behind the Hufen Edikt, not only by ignoring the existence of massive archival evidence that shows the deep concern over declining subsistence levels 
expressed by the Hessian estates and officials of all ranks, but also by confusing my own book's narration of the regime's motives in issuing the edict with its later examination of the unintended effects that it had on military recruitment.

But these are small matters compared to what Taylor does not say in his response to my review. He does not deny that he grossly misrepresented the creation of the Landräte as a strategy for army recruitment. Nor does he challenge the disclosure that his "Hessian" fairy tales came from somewhere else. He does not dispute his willful misrepresentation of England's guarantee of the Protestant succession, the government's policy toward vagabonds, or the enormous body of government initiatives aimed at providing gainful civilian employment. He never defends his fanciful, undocumented musings about the likely negative consequences of all things military. Nor do I suspect that he wishes to make an issue of his misleading use of footnotes or his penchant for impenetrable jargon. Indeed, the great bulk of my criticism reflects my keen disappointment (not anger) that Taylor has chosen to be an advocate who feels that he can ignore evidence in "suggesting" one thing, when a serious scholar would deal with all of the evidence and not only the sources that confirm his own theories. It is primarily because of this lapse in scholarly judgment that he and his book fail the test of good scholarship. 